\title{
Vitamin D Binding Protein Impact on 25-Hydroxyvitamin D Levels under Different Physiologic and Pathologic Conditions
}

\author{
Pegah Yousefzadeh, ${ }^{1}$ Sue A. Shapses, ${ }^{2}$ and Xiangbing Wang ${ }^{1}$ \\ ${ }^{1}$ Division of Endocrinology, Metabolism \& Nutrition, Department of Medicine, Rutgers University-Robert Wood Johnson \\ Medical School, New Brunswick, NJ 08903, USA \\ ${ }^{2}$ Department of Nutritional Sciences, Rutgers University, New Brunswick, NJ 08901, USA
}

Correspondence should be addressed to Xiangbing Wang; wangx9@rwjms.rutgers.edu

Received 18 January 2014; Revised 3 April 2014; Accepted 10 April 2014; Published 28 April 2014

Academic Editor: Zhongjian Xie

\begin{abstract}
Copyright ( 2014 Pegah Yousefzadeh et al. This is an open access article distributed under the Creative Commons Attribution License, which permits unrestricted use, distribution, and reproduction in any medium, provided the original work is properly cited.

There is a high prevalence of vitamin D deficiency worldwide, but how to define vitamin D deficiency is controversial. Currently, the plasma concentration of total 25 -hydroxyvitamin $\mathrm{D}[25(\mathrm{OH}) \mathrm{D}]$ is considered an indicator of vitamin $\mathrm{D}$ status. The free hormone hypothesis states that protein-bound hormones are inactive while unbound hormones are free to exert biological activity. The majority of circulating $25(\mathrm{OH}) \mathrm{D}$ and $1,25(\mathrm{OH})_{2} \mathrm{D}$ is tightly bound to vitamin D binding protein (DBP), $10-15 \%$ is bound to albumin, and less than $1 \%$ of circulating vitamin D exists in an unbound form. While DBP is relatively stable in most healthy populations, a recent study showed that there are gene polymorphisms associated with race and ethnicity that could alter DBP levels and binding affinity. Furthermore, in some clinical situations, total vitamin D levels are altered and knowing whether DBP is also altered may have treatment implications. The aim of this review is to assess DBP concentration in different physiological and pathophysiological conditions. We suggest that DBP should be considered in the interpretation of $25(\mathrm{OH}) \mathrm{D}$ levels.
\end{abstract}

\section{Introduction}

Reports of the worldwide prevalence of low vitamin D status vary depending on the level of total 25-hydroxyvitamin $\mathrm{D}$ $[25(\mathrm{OH}) \mathrm{D}]$ that is used to define vitamin D sufficiency. The plasma concentration of total $25(\mathrm{OH}) \mathrm{D}$ is considered an indicator of vitamin D status due to its long half-life of $15-$ 35 days and lack of hormonal control of the hepatic 25hydroxylase [1]. The free hormone hypothesis states that protein-bound hormones are relatively inactive while hormones not bound to binding proteins are available to exert biological activity [2]. The majority (85-90\%) of circulating $25(\mathrm{OH}) \mathrm{D}$ and $1,25(\mathrm{OH})_{2} \mathrm{D}$ is tightly bound to DBP, with a smaller amount (10-15\%) bound to albumin. Less than $1 \%$ of circulating vitamin $\mathrm{D}$ exists in a free, unbound form $[3,4]$. It is difficult to define vitamin D deficiency because circulating $25(\mathrm{OH}) \mathrm{D}$ levels vary in different physiologic and disease states. It is unclear whether a change in levels of DBP would have any effect on concentrations of vitamin D metabolites, as DBP circulates at a higher level than its ligands. In a recent study, it was reported that despite the lower levels of total 25(OH)D and DBP in blacks compared to whites, both groups had similar concentrations of estimated bioavailable $25(\mathrm{OH}) \mathrm{D}$ and can be explained by a difference in polymorphisms in the DBP gene [5]. Another recent study used a novel immunoassay to directly measure free $25(\mathrm{OH}) \mathrm{D}$, and they concluded that the current algorithms to calculate free $25(\mathrm{OH}) \mathrm{D}$ may not be accurate and further investigation is required [6]. A new assay that measures free serum $25(\mathrm{OH}) \mathrm{D}$ directly is now available by the Future Diagnostics (Wijchen, The Netherlands), but it is labor intensive, costly, and time-consuming. Alternatively, the bioavailable and DBP-bound $25(\mathrm{OH}) \mathrm{D}$ can be calculated using equations adapted from Vermeulen et al. [7] and is currently being used in clinical practice [8]. Recent studies have found that serum DBP and vitamin D levels are decreased in type 1 diabetes mellitus (T1DM) [9], chronic liver [10], and renal diseases [11], while pregnancy and oral contraceptive pills (OCP) increase DBP and vitamin D levels $[12,13]$. On the other hand, in a large cohort of healthy adults with sufficient 
vitamin D levels, the biological effects of vitamin $\mathrm{D}$ on PTH levels are mainly independent of DBP concentration [14]. This finding may provide useful information for studies investigating the relationship between $25(\mathrm{OH}) \mathrm{D}$ and $\mathrm{DBP}$ in different age groups, races, and disease states. Dynamic changes of DBP levels should be integrated into interpreting the serum levels of $25(\mathrm{OH}) \mathrm{D}$ in these conditions. Besides binding to vitamin D metabolites, DBP has other physiological functions, including interacting with target organ or cells. In addition, megalin, possibly in conjunction with cubilin, mediates uptake of DBP-bound $25(\mathrm{OH}) \mathrm{D}$ into the kidney for the intracrine conversion of $25(\mathrm{OH}) \mathrm{D}$ to $1,25(\mathrm{OH}) \mathrm{D}$ [4]. Megalin may also play a role in extrarenal tissues [4]. The aim of this review is to discuss the correlation between serum levels of DBP and $25(\mathrm{OH}) \mathrm{D}$ in various physiologic and pathologic conditions.

\section{Physiological Factors Affecting DBP and 25(OH)D Levels}

2.1. Race and DBP Genotype. There is a higher prevalence of vitamin D deficiency among African Americans, as their total $25(\mathrm{OH}) \mathrm{D}$ levels are lower than those in white individuals. This could be due to their lower cutaneous synthesis of vitamin D [15]. Levels of total $25(\mathrm{OH}) \mathrm{D}$ are in part genetically determined. Variations in the DBP originally referred to as GC1F, GC1S, and GC2 were first reported more than 50 years ago and may be associated with changes in binding affinity or serum concentration of DBP. The protein variants are now recognized as resulting from polymorphisms in the DBP binding protein gene GC. The phenotypic variations in the DBP amino acid sequence are distinguished by single nucleotide polymorphisms (SNPs) rs7041 and rs4588. Blacks and Asians are more likely to carry GC1F DBP, which has the highest affinity for 25(OH)D and is associated with low DBP levels. Whites are more likely to carry GC1S DBP. GC2, which has a lower affinity for $25(\mathrm{OH}) \mathrm{D}$ and is associated with higher DBP levels, is frequently found in whites and rarely found in blacks $[4,5]$. The high prevalence of GC1F in blacks results in concentrations of bioavailable $25(\mathrm{OH}) \mathrm{D}$ similar to those in whites [5]. Engelman et al. [16] showed that homozygosity for the CG1F allele (DDTT) occurred in 53\% of African Americans but only $6 \%$ of Caucasians and $13 \%$ of Hispanics. The rs4588 and rs7041 SNPs were associated with 25(OH)D levels in Hispanics and African Americans. Combinations of these alleles appear to alter DBP concentration, the affinity for $25(\mathrm{OH}) \mathrm{D}$, and $25(\mathrm{OH})$ levels $[17,18]$. In a cross-section study, Santos et al. found that the AA genotype of rs4588 and TT genotypic of rs7044 and CT-AT/AT-AT (GC1f-2/2-2) were associated with lower $25(\mathrm{OH}) \mathrm{D}$ levels in healthy girl [19]. The rs4588 and rs7041 SNPs were associated with $25(\mathrm{OH}) \mathrm{D}$ levels and rs4588 was associated with $1,25(\mathrm{OH})_{2} \mathrm{D}$ levels in Hispanics and African Americans [16]. Cheung et al. [20] in a study of Southern Chinese women found that among four SNPs (rs2282679, rs10741657, rs12785878, and rs6013897), rs2282679 was associated with serum $25(\mathrm{OH}) \mathrm{D}$ levels and vitamin D insufficiency while rs12785878 was associated with vitamin D insufficiency only.
2.2. Age and Gender. Age appears to have an impact on DBP concentration, as it does on other globulins such as sex hormone binding protein (SHBG) and insulin-like growth factor binding protein (IGFBP). Vitamin D insufficiency is common among older adults. Our recent study showed that DBP was negatively correlated with age in female subjects indicating that age might be an independent factor affecting DBP and 25(OH)D levels [21]. Carpenter et al. [22] suggested that in young children genetic variance of the common rs 4588 affects circulating levels of the DBP, which in turn affects circulating 25(OH)D levels in infants and toddlers. The GC genotype may be related to the susceptibility to low $25(\mathrm{OH}) \mathrm{D}$ levels in female children and adolescents. The GC genotype also affects circulating 25(OH)D independent of its effect on circulating DBP. Genome-wide association studies have found an association between variants in the GC genotypes and serum levels of 25(OH)D and PHT in older adults [23]. Winters et al. [24] found that DBP was not an important determinant of circulating $25(\mathrm{OH}) \mathrm{D}$ in women, nor was it affected by race or adiposity. In a study in which DBP levels were assessed in 100 healthy, middle-aged, and older participants, it was found that women had higher mean DBP levels than men, but no associations were observed between DBP levels and age, body weight, BMI, fat mass, or fat percentage [25]. Blanton et al. [9] confirmed that DBP levels were lower in males than in females, which could be due to estrogen effects on DBP.

2.3. Pregnancy and Estrogen. The increase in DBP levels associated with pregnancy results from the stimulation of DBP synthesis by estrogen [12]. It has been shown that while $\mathrm{DBP}$ is higher in pregnancy, free $25(\mathrm{OH}) \mathrm{D}$ is not lower, which can be attributed to weaker binding to DBP [26]. The use of OCP may also affect 25(OH)D concentrations and DBP levels. The limited data available on the effects of OCP on $25(\mathrm{OH}) \mathrm{D}$ concentrations suggest no change or an increase in total 25(OH)D [13], whereas most studies consistently report an increase in levels of $1,25(\mathrm{OH})_{2} \mathrm{D}$ and DBP [27].

DBP may be regulated by various hormone levels, as is the case with other globulins such as sex hormone binding globulin (SHBG) and thyroid binding globulin (TBG). Egawa et al. [28] reported that the DBP production might be regulated by insulin, estradiol, triamcinolone, dihydrotestosterone, or epidermal growth factor. The use of OCP is associated with $13 \%-25 \%$ higher concentrations of total $25(\mathrm{OH}) \mathrm{D}$ and $1,25(\mathrm{OH})_{2} \mathrm{D}$ and DBP. The estrogen component of OCP may increase DBP synthesis or decrease its catabolism. The authors suggest that use of OCP should be considered in the interpretation of plasma concentrations of vitamin D metabolites [13]. Our recent preliminary findings showed that DBP and 25(OH)D were lower in postmenopausal women compared with premenopausal women [21]. Consistent with this finding, the initiation of estrogen therapy in postmenopausal women caused a significant $8 \%$ increase in DBP levels [29] also suggesting that estrogen is a factor affecting $\mathrm{DBP}$ and 25(OH)D levels. 
2.4. Obesity. The association between reduced $25(\mathrm{OH}) \mathrm{D}$ concentrations and obesity is well established, although the mechanisms for the lower $25(\mathrm{OH}) \mathrm{D}$ concentrations are not fully described. In a recent report, it was shown that DBP was lower in obese adolescents compared to those with normal weight and there was a positive correlation between DBP and $25(\mathrm{OH}) \mathrm{D}$ levels. The authors also reported that there was an inverse relationship between insulin levels and DBP levels in obese adolescents even when corrected for adiposity. It was suggested that insulin suppresses the production of DBP [30]. Obese women had higher DBP concentrations and lower free $25(\mathrm{OH}) \mathrm{D}$ compared with normal-weight women and a lower free $25(\mathrm{OH}) \mathrm{D}$ level. The obese women were more likely to have $25(\mathrm{OH}) \mathrm{D}$ concentrations that could be considered suboptimal [31].

\section{Pathologic Factors Affecting DBP and 25(OH)D Levels}

3.1. Liver Disease. The liver is where 25-hydroxylation of vitamin D occurs and the majority of DBP is synthesized. The prevalence of vitamin $\mathrm{D}$ insufficiency is particularly high in patients with chronic liver disease. Vitamin D deficiency or low total vitamin D levels in chronic liver disease is likely to result from a number of mechanisms including lower levels of sun exposure and inadequate dietary intake of vitamin D. Serum $25(\mathrm{OH}) \mathrm{D}$ levels are inversely related to the severity of chronic liver disease [32]. Decreased production of DBP and albumin, which also carries vitamin $\mathrm{D}$, might be critical in chronic liver disease $[10,33]$. However, patients with cirrhosis and low albumin concentrations have higher free 25(OH)D levels [26]. Patients with end-stage liver diseases had a high prevalence of low total $25(\mathrm{OH})$ but maintained normal serum corrected calcium levels and did not develop secondary hyperparathyroidism [33]. Low total Vitamin D and low DBP levels in liver failure can be corrected with a liver transplant after which serum DBP and albumin increase substantially. Low DBP levels likely have a role in low total vitamin D levels in profound liver dysfunction [34].

3.2. Renal Disease. Low total vitamin D levels are common in patients with chronic kidney disease (CKD) at all stages. An alteration in megalin-dependent uptake of DBP in the kidney [4] in CKD would be expected to decrease the intracrine conversion of $25(\mathrm{OH}) \mathrm{D}$ to $1,25(\mathrm{OH}) \mathrm{D}$ leading to complications, such as renal osteodystrophy. Increased urinary excretion of DBP has been associated with tubular dysfunction, such as in patients with nephrotic syndrome [35] and renal Fanconi syndrome [36]. Increased urinary loss of DBP has been postulated to contribute to the low total vitamin $\mathrm{D}$ levels in patients with proteinuria. However, a recent study by Doorenbos et al. [37] found that antiproteinuric treatment reduced urinary loss of DBP, but did not affect $25(\mathrm{OH}) \mathrm{D}$ levels in CKD. This is consistent with the hypothesis that urinary DBP is a marker of renal interstitial inflammation and fibrosis [38]. When compared to white patients, black patients receiving hemodialysis had lower levels of total $25(\mathrm{OH}) \mathrm{D}$, but similar levels of bioavailable $25(\mathrm{OH}) \mathrm{D}$ levels. Bioavailable
$25(\mathrm{OH}) \mathrm{D}$ levels but not total $25(\mathrm{OH}) \mathrm{D}$ and $1,25(\mathrm{OH})_{2} \mathrm{D}$ were significantly correlated with serum calcium [39]. It has also been shown that children with CKD exhibit altered concentration of DBP and bioavailable $25(\mathrm{OH})$, and there is an important impact of their underlying disease [11]. These findings suggest that bioavailable vitamin $\mathrm{D}$ levels are better correlated with measures of mineral metabolism than total vitamin $\mathrm{D}$ levels in patients receiving hemodialysis.

3.3. Diabetes. Blanton et al. [9] showed that serum DBP levels are decreased in patients with T1DM compared to healthy controls. They suggested that multiple components in the metabolic pathway of vitamin $\mathrm{D}$ may be altered in T1DM and, collectively, have the potential to influence disease pathogenesis. Another study showed that urinary loss of DBP in T1DM was higher compared to healthy individuals suggesting that urinary loss of DBP might contribute to the lower levels of serum 25(OH)D [40]. Tian et al. [41] found that DBP was higher in diabetic patients with nephropathy and microalbuminuria or macroalbuminuria compared to healthy controls or diabetic patients with normoalbuminuria. They suggested that urinary DBP is a potential biomarker for early detection of diabetic nephropathy.

3.4. Primary Hyperparathyroidism (PHPT). Low total $25(\mathrm{OH}) \mathrm{D}$ levels are commonly encountered in patients with PHPT. The causes are not totally understood, but proposed mechanisms include stimulation by PTH of the conversion of $25(\mathrm{OH}) \mathrm{D}$ to $1,25(\mathrm{OH})_{2} \mathrm{D}$ by $1 \alpha$-hydroxylase and the increased catabolism of $25(\mathrm{OH}) \mathrm{D}$ by CYP24A1 induced by the high levels of $1,25(\mathrm{OH})_{2} \mathrm{D}$ that prevail in PHPT [42]. We previously reported that both serum $25(\mathrm{OH}) \mathrm{D}$ and $\mathrm{DBP}$ levels were significantly lower in female patients with PHPT compared with control subjects. DBP levels were inversely correlated with intact $\mathrm{PTH}$, suggesting that $\mathrm{PTH}$ regulates DBP production [43]. The findings suggest that a low DBP level contributes to the low $25(\mathrm{OH}) \mathrm{D}$ level observed in female PHPT patients.

3.5. Cancer. There are several reports that there is an association between vitamin $\mathrm{D}$ deficiency and risk of developing cancer. A recent meta-analysis suggested an inverse association of $25(\mathrm{OH}) \mathrm{D}$ with total cancer incidence and mortality [44]. However, Weinstein et al. [45] reported that $25(\mathrm{OH}) \mathrm{D}$ levels were positively correlated with pancreatic cancer risk and DBP was inversely associated with pancreatic cancer risk. Higher DBP concentrations may result in increased bound $25(\mathrm{OH}) \mathrm{D}$ and reduced free $25(\mathrm{OH}) \mathrm{D}$. These authors suggest that simultaneous examination of DBP and $25(\mathrm{OH}) \mathrm{D}$ may be important in determining the association of vitamin $\mathrm{D}$ and cancer risk. In another study, the same authors found that serum DBP was not associated with prostate cancer risk overall; however, high serum DBP was associated with significantly decreased risk of prostate cancer in men with lower $25(\mathrm{OH}) \mathrm{D}$ concentrations and increased risk in men with higher $25(\mathrm{OH}) \mathrm{D}$. These data suggest that the primary vitamin D carrier protein DBP modulates the impact of vitamin D status on prostate cancer [46]. Together, these data 
suggest that the combination of both $\mathrm{DBP}$ and $25(\mathrm{OH}) \mathrm{D}$ is needed to understand cancer risk $[45,46]$. Mondul et al. [47] reported that low serum $25(\mathrm{OH}) \mathrm{D}$ levels were associated with a higher risk of bladder cancer and provided data to support an etiologic role for vitamin D in bladder cancer. They suggested that free circulating vitamin $\mathrm{D}$ might be a more relevant factor when examining bladder and other cancers. Overall, the data for cancer is still emerging and the role of DBP requires further study.

3.6. HIV and Inflammation. Comparing over $200 \mathrm{HIV}-$ infected youth on stable treatment with regimens containing tenofovir disoproxil fumarate (TDF) to those whose treatment lacked TDF, Havens et al. [48] found that the higher plasma tenofovir concentrations were associated with higher DBP and lower free $1,25(\mathrm{OH})_{2} \mathrm{D}$. This might imply a functional vitamin $\mathrm{D}$ deficiency and can explain the TDFassociated increase in parathyroid hormone.

It is also common to see vitamin D insufficiency in hospitalized patients with an acute illness. DBP level is decreased in acute inflammatory conditions. One study showed that, following surgery, the mean CRP increased but both serums 25(OH)D and DBP decreased [49]. Patients with sepsis have a high mortality rate as well as a high prevalence of vitamin $\mathrm{D}$ deficiency. In addition, septic patients have decreased DBP levels, which further exacerbate the total low vitamin D levels but might attenuate the risk of vitamin $\mathrm{D}$ deficiency by maintaining normal free or bioavailable 25(OH)D [50]. Jeng et al. found that $25(\mathrm{OH}) \mathrm{D}$ and DBP levels were lower in patients in the intensive care unit with sepsis compared with healthy controls [51]. Serum $25(\mathrm{OH}) \mathrm{D}$ may be an unreliable biomarker of vitamin $\mathrm{D}$ status after acute inflammatory insult.

3.7. Procedures. Plasma exchange is a therapeutic procedure that is used to remove pathogenic circulating proteins from patients' plasma, and it often results in the depletion of physiologically important proteins including DBP. Plasma exchange induced an acute reversible decrease in plasma 1, $25(\mathrm{OH})_{2} \mathrm{D}, \mathrm{DBP}$, and calcium and a sustained decrease in plasma 25(OH)D [52]. Another study showed that, in CKD stages 4-5 children on peritoneal dialysis (PD), urinary DBP losses were $>300$-fold higher than seen in age-matched healthy children and correlated with urinary albumin loss. They concluded that peritoneal DBP losses mirror both dialysate and urinary albumin losses and are associated with a longer dialysis vintage but do not contribute to vitamin $\mathrm{D}$ deficiency in children on PD [53]. These findings suggest that serum $25(\mathrm{OH}) \mathrm{D}$ may be an unreliable biomarker of vitamin $\mathrm{D}$ status after procedures such as plasma exchange and PD.

\section{Conclusion}

Different physiologic and pathologic conditions can affect DBP levels, which in turn affect circulating $25(\mathrm{OH}) \mathrm{D}$ levels. Therefore, alterations in DBP levels should be considered as potential confounders on the interpretation of plasma total $25(\mathrm{OH}) \mathrm{D}$ concentrations. Further research is required to assess whether the free $25(\mathrm{OH}) \mathrm{D}$ index as compared to total $25(\mathrm{OH}) \mathrm{D}$ levels is a better marker of $25(\mathrm{OH}) \mathrm{D}$ tissue availability and if it has a higher correlation with indices of skeletal and nonskeletal outcomes.

\section{Conflict of Interests}

The authors declare that there is no conflict of interests regarding the publication of this paper.

\section{Acknowledgments}

The authors are grateful to Stephen H. Schneider, M.D. degree holder, Louis Amorosa, M.D. degree holder, and Xinjiang Cai, M.D. and Ph.D. degrees holder, and their insightful discussions. Vincent A. Rifici, Ph.D. degree holder, assisted in the preparation of this paper.

\section{References}

[1] M. F. Holick, "Resurrection of vitamin D deficiency and rickets," The Journal of Clinical Investigation, vol. 116, no. 8, pp. 20622072, 2006.

[2] C. M. Mendel, "The free hormone hypothesis: a physiologically based mathematical model," Endocrine Reviews, vol. 10, no. 3, pp. 232-274, 1989.

[3] D. D. Bikle, P. K. Siiteri, and E. Ryzen, "Serum protein binding of 1,25-dihydroxyvitamin $\mathrm{D}$ : a reevaluation by direct measurement of free metabolite levels," The Journal of Clinical Endocrinology \& Metabolism, vol. 61, no. 5, pp. 969-975, 1985.

[4] R. F. Chun, B. E. Peercy, E. S. Orwoll, C. M. Nielson, J. S. Adams, and M. Hewison, "Vitamin D and DBP: the free hormone hypothesis revisited," The Journal of Steroid Biochemistry and Molecular Biology, 2013.

[5] C. E. Powe, M. K. Evans, J. Wenger, A. B. Zonderman, A. H. Berg, M. Nalls et al., "Vitamin D-binding protein and vitamin D status of black Americans and white Americans," The New England Journal of Medicine, vol. 369, no. 21, pp. 1991-2000, 2013.

[6] J. B. Schwartz, J. Lai, B. Lizaola et al., "A comparison of direct and calculated free 25(OH) Vitamin D levels in clinical populations," The Journal of Clinical Endocrinology \& Metabolism, 2014.

[7] A. Vermeulen, L. Verdonck, and J. M. Kaufman, "A critical evaluation of simple methods for the estimation of free testosterone in serum," The Journal of Clinical Endocrinology \& Metabolism, vol. 84, no. 10, pp. 3666-3672, 1999.

[8] D. D. Bikle, E. Gee, B. Halloran, and J. G. Haddad, "Free 1,25dihydroxyvitamin D levels in serum from normal subjects, pregnant subjects, and subjects with liver disease," The Journal of Clinical Investigation, vol. 74, no. 6, pp. 1966-1971, 1984.

[9] D. Blanton, Z. Han, L. Bierschenk et al., "Reduced serum vitamin D-binding protein levels are associated with type 1 diabetes," Diabetes, vol. 60, no. 10, pp. 2566-2570, 2011.

[10] C. S. Stokes, D. A. Volmer, F. Grünhage, and F. Lammert, "Vitamin D in chronic liver disease," Liver International, vol. 33, no. 3, pp. 338-352, 2013.

[11] M. R. Denburg, H. J. Kalkwarf, I. H. de Boer, M. Hewison, J. Shults, B. S. Zemel et al., "Vitamin D bioavailability and catabolism in pediatric chronic kidney disease," Pediatric Nephrology, vol. 28, no. 9, pp. 1843-1853, 2013. 
[12] U. K. Møller, S. Streym, L. Heickendorff, L. Mosekilde, and L. Rejnmark, "Effects of 25(OH)D concentrations on chances of pregnancy and pregnancy outcomes: a cohort study in healthy Danish women," European Journal of Clinical Nutrition, vol. 66, pp. 862-868, 2012.

[13] U. K. Moller, S. V. Streym, L. T. Jensen et al., "Increased plasma concentrations of vitamin D metabolites and vitamin D binding protein in women using hormonal contraceptives: a crosssectional study," Nutrients, vol. 5, no. 9, pp. 3470-3480, 2013.

[14] Z. Dastani, C. Berger, L. Langsetmo, L. Fu, B. Y. Wong, S. Malik et al., "In healthy adults, biological activity of vitamin $\mathrm{D}$, as assessed by serum PTH, is largely independent of DBP concentrations," Journal of Bone and Mineral Research, vol. 29, no. 2, pp. 494-499, 2014.

[15] S. Nesby-O’Dell, K. S. Scanlon, M. E. Cogswell et al., "Hypovitaminosis D prevalence and determinants among African American and white women of reproductive age: third National Health and Nutrition Examination Survey, 1988-1994," American Journal of Clinical Nutrition, vol. 76, no. 1, pp. 187-192, 2002.

[16] C. D. Engelman, T. E. Fingerlin, C. D. Langefeld et al., "Genetic and environmental determinants of 25-hydroxyvitamin D and 1,25-dihydroxyvitamin D levels in hispanic and African Americans," The Journal of Clinical Endocrinology \& Metabolism, vol. 93, no. 9, pp. 3381-3388, 2008.

[17] T. J. Wang, F. Zhang, J. B. Richards et al., "Common genetic determinants of vitamin D insufficiency: a genome-wide association study. .," The Lancet, vol. 376, no. 9736, pp. 180-188, 2010.

[18] G. P. Levin, C. Robinson-Cohen, I. H. De Boer, D. K. Houston, K. Lohman, Y. Liu et al., "Genetic variants and associations of 25-hydroxyvitamin $\mathrm{D}$ concentrations with major clinical outcomes," The Journal of the American Medical Association, vol. 308, no. 18, pp. 1898-1905, 2012.

[19] B. R. Santos, L. P. Mascarenhas, M. C. Boguszewski, and P. M. Spritzer, "Variations in the vitamin D-binding protein (DBP) gene are related to lower 25-hydroxyvitamin D levels in healthy girls: a cross-sectional study," Hormone Research in Paediatrics, vol. 79, pp. 162-168, 2013.

[20] C. L. Cheung, K. S. Lau, P. C. Sham, K. C. Tan, and A. W. Kung, "Genetic variant in vitamin D binding protein is associated with serum 25-hydroxyvitamin D and vitamin D insufficiency in southern Chinese," Journal of Human Genetics, vol. 58, pp. 749751, 2013 .

[21] X. Wang and S. A. Shapses, "Vitamin D binding protein levels in normal pre-and post menopausal women," Endocrine Reviews, vol. 34, 2013.

[22] T. O. Carpenter, J. H. Zhang, E. Parra, B. K. Ellis, C. Simpson, and W. M. Lee, "Vitamin D binding protein is a key determinant of 25-hydroxyvitamin D levels in infants and toddlers," Journal of Bone and Mineral Research, vol. 28, no. 1, pp. 213-221, 2013.

[23] L. Perna, J. F. Felix, L. P. Breitling et al. et al., "Genetic variations in the vitamin D binding protein and season-specific levels of vitamin D among older adults," Epidemiology, vol. 24, no. 1, pp. 104-109, 2013.

[24] S. J. Winters, R. Chennubhatla, C. Wang, and J. J. Miller, "Influence of obesity on vitamin D-binding protein and 25hydroxy vitamin D levels in African American and white women," Metabolism: Clinical and Experimental, vol. 58, no. 4, pp. 438-442, 2009.

[25] M. J. Bolland, A. B. Grey, R. W. Ames et al., "Age-, gender-, and weight-related effects on levels of 25-hydroxyvitamin D are not mediated by vitamin D binding protein," Clinical Endocrinology, vol. 67 , no. 2, pp. 259-264, 2007.
[26] J. B. Schwartz, J. Lai, B. Lizaola et al., "Variability in free $25(\mathrm{OH})$ vitamin D levels in clinical populations," The Journal of Steroid Biochemistry and Molecular Biology, 2013.

[27] R. Bouillon, F. A. van Assche, H. van Baelen, W. Heyns, and P. de Moor, "Influence of the vitamin D-binding protein on the serum concentration of 1,25-dihydroxyvitamin D3. Significance of the free 1,25-dihydroxyvitamin D3 concentration," The Journal of Clinical Investigation, vol. 67, no. 3, pp. 589-596, 1981.

[28] T. Egawa, H. Ito, H. Nakamura, H. Yamamoto, and S. Kishimoto, "Hormonal regulation of vitamin D-binding protein production by a human hepatoma cell line," Biochemistry International, vol. 28, no. 3, pp. 551-557, 1992.

[29] L. Rejnmark, A. L. Lauridsen, C. Brot et al., "Vitamin D and its binding protein Gc: long-term variability in peri- and postmenopausal women with and without hormone replacement therapy," Scandinavian Journal of Clinical and Laboratory Investigation, vol. 66, no. 3, pp. 227-238, 2006.

[30] A. P. Ashraf, C. Huisingh, J. A. Alvarez, X. Wang, and B. A. Gower, "Insulin resistance indices are inversely associated with vitamin D binding protein concentrations," The Journal of Clinical Endocrinology \& Metabolism, vol. 99, no. 1, pp. 178-183, 2014.

[31] T. Karlsson, A. Osmancevic, N. Jansson, L. Hulthén, A. Holmäng, and I. Larsson, "Increased vitamin D-binding protein and decreased free $25(\mathrm{OH}) \mathrm{D}$ in obese women of reproductive age," European Journal of Nutrition, vol. 53, no. 1, pp. 259-267, 2014.

[32] M. Malham, S. P. Jørgensen, P. Ott et al., "Vitamin D deficiency in cirrhosis relates to liver dysfunction rather than aetiology," World Journal of Gastroenterology, vol. 17, no. 7, pp. 922-925, 2011.

[33] R. L. Corey, M. D. Whitaker, M. D. Crowell, M. T. Keddis, B. Aqel, V. Balan et al., "Vitamin D deficiency, parathyroid hormone (PTH) levels, and bone disease among patients with end stage liver disease (ESLD) and normal serum creatinine awaiting liver transplantation (LT)," Clinical Transplantation, 2014.

[34] P. P. Reese, R. D. Bloom, H. I. Feldman et al., "Changes in vitamin $\mathrm{D}$ binding protein and vitamin D concentrations associated with liver transplantation," Liver International, vol. 32, no. 2, pp. 287-296, 2012.

[35] K. Colston, N. J. Williams, and H. J. W. Cleeve, "Studies on vitamin D binding protein in the nephrotic syndrome," Clinical Chemistry, vol. 31, no. 5, pp. 718-721, 1985.

[36] A. Vilasi, P. R. Cutillas, A. D. Maher et al., "Combined proteomic and metabonomic studies in three genetic forms of the renal Fanconi syndrome," American Journal of Physiology-Renal Physiology, vol. 293, no. 2, pp. F456-F467, 2007.

[37] C. R. C. Doorenbos, M. M. de Cuba, L. Vogt et al., "Antiproteinuric treatment reduces urinary loss of vitamin D-binding protein but does not affect vitamin D status in patients with chronic kidney disease," Journal of Steroid Biochemistry and Molecular Biology, vol. 128, no. 1-2, pp. 56-61, 2012.

[38] K. Mirkovic, C. R. Doorenbos, W. A. Dam, H. J. Lambers Heerspink, M. C. Slagman, F. L. Nauta et al., "Urinary vitamin $D$ binding protein: a potential novel marker of renal interstitial inflammation and fibrosis," PLoS ONE, vol. 8, Article ID e55887, 2013.

[39] I. Bhan, C. E. Powe, A. H. Berg et al., "Bioavailable vitamin D is more tightly linked to mineral metabolism than total vitamin $\mathrm{D}$ in incident hemodialysis patients," Kidney International, vol. 82, pp. 84-89, 2012. 
[40] K. M. Thrailkill, C.-H. Jo, G. E. Cockrell, C. S. Moreau, and J. L. Fowlkes, "Enhanced excretion of vitamin D binding protein in type 1 diabetes: a role in vitamin D deficiency?" The Journal of Clinical Endocrinology \& Metabolism, vol. 96, no. 1, pp. 142-149, 2011.

[41] X. Q. Tian, L. M. Zhao, J. P. Ge, Y. Zhang, and Y. C. Xu, "Elevated urinary level of vitamin D-binding protein as a novel biomarker for diabetic nephropathy," Experimental and Therapeutic Medicine, vol. 7, no. 2, pp. 411-416, 2014.

[42] M. R. Clements, M. Davies, M. E. Hayes et al., "The role of 1,25dihydroxyvitamin $\mathrm{D}$ in the mechanism of acquired vitamin $\mathrm{D}$ deficiency," Clinical Endocrinology, vol. 37, no. 1, pp. 17-27, 1992.

[43] X. Wang, S. A. Shapses, S. Wei, D. Sukumar, and J. Ghosh, "Vitamin D binding protein levels in female patients with primary hyperparathyroidism," Endocrine Practice, vol. 19, no. 4, pp. 609-613, 2013.

[44] L. Yin, J. M. Ordóñez-Mena, T. Chen, B. Schöttker, V. Arndt, and H. Brenner, "Circulating 25-hydroxyvitamin D serum concentration and total cancer incidence and mortality: a systematic review and meta-analysis," Preventive Medicine, vol. 57, no. 6, pp. 753-764, 2013.

[45] S. J. Weinstein, R. Z. Stolzenberg-Solomon, W. Kopp, H. Rager, J. Virtamo, and D. Albanes, "Impact of circulating vitamin D binding protein levels on the association between 25hydroxyvitamin $\mathrm{d}$ and pancreatic cancer risk: a nested casecontrol study," Cancer Research, vol. 72, no. 5, pp. 1190-1198, 2012.

[46] S. J. Weinstein, A. M. Mondul, W. Kopp, H. Rager, J. Virtamo, and D. Albanes, "Circulating 25-hydroxyvitamin D, vitamin D-binding protein and risk of prostate cancer," International Journal of Cancer, vol. 132, no. 12, pp. 2940-2947, 2013.

[47] A. M. Mondul, S. J. Weinstein, J. Virtamo, and D. Albanes, "Influence of vitamin D binding protein on the association between circulating vitamin D and risk of bladder cancer," British Journal of Cancer, vol. 107, no. 9, pp. 1589-1594, 2012.

[48] P. L. Havens, J. J. Kiser, C. B. Stephensen, R. Hazra, P. M. Flynn, C. M. Wilson et al., "Association of higher plasma vitamin D binding protein and lower free calcitriol levels with tenofovir disoproxil fumarate use and plasma and intracellular tenofovir pharmacokinetics: cause of a functional vitamin d deficiency," Antimicrobial Agents and Chemotherapy, vol. 57, no. 11, pp. 56195628, 2013.

[49] J. L. Waldron, H. L. Ashby, M. P. Cornes, J. Bechervaise, C. Razavi, O. L. Thomas et al., "Vitamin D: a negative acute phase reactant," Journal of Clinical Pathology, vol. 66, no. 7, pp. 620622, 2013.

[50] R. R. Watkins, A. V. Yamshchikov, T. L. Lemonovich, and R. A. Salata, "The role of vitamin D deficiency in sepsis and potential therapeutic implications," Journal of Infection, vol. 63, no. 5, pp. 321-326, 2011.

[51] L. Jeng, A. V. Yamshchikov, S. E. Judd et al., "Alterations in vitamin D status and anti-microbial peptide levels in patients in the intensive care unit with sepsis," Journal of Translational Medicine, vol. 7, article 28, 2009.

[52] T. F. Hiemstra, A. Casian, P. Boraks, D. R. Jayne, and I. Schoenmakers, "Plasma exchange induces vitamin D deficiency," QJM, vol. 107, no. 2, pp. 120-130, 2014.

[53] A. Prytuła, D. Wells, T. McLean et al., "Urinary and dialysate losses of vitamin D-binding protein in children on chronic peritoneal dialysis," Pediatric Nephrology, vol. 27, no. 4, pp. 643649, 2012. 


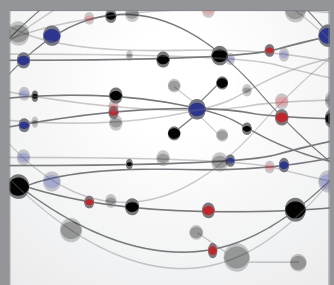

The Scientific World Journal
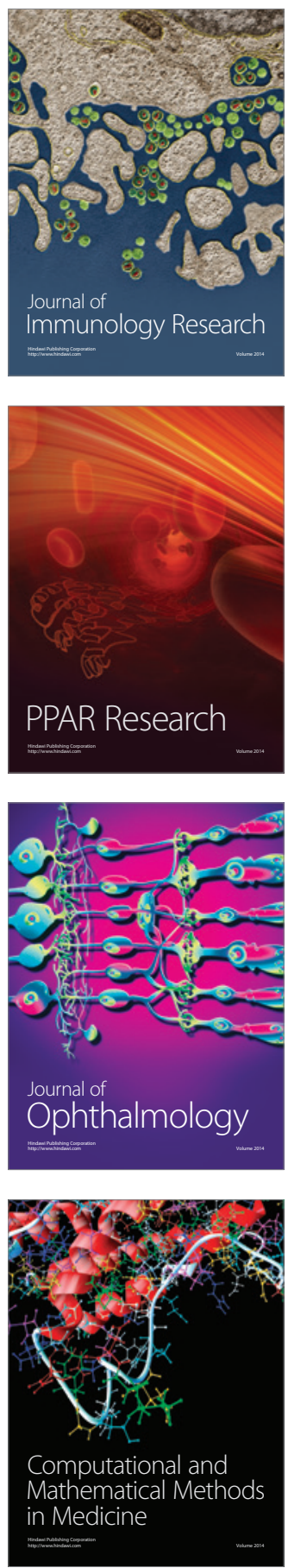

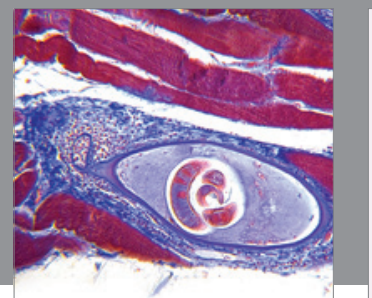

Gastroenterology

Research and Practice
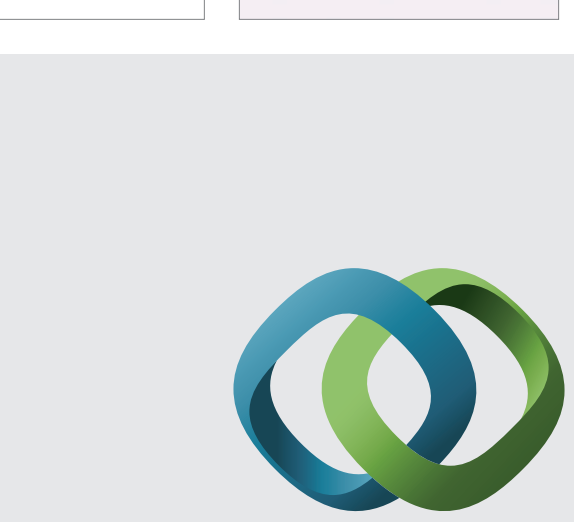

\section{Hindawi}

Submit your manuscripts at

http://www.hindawi.com
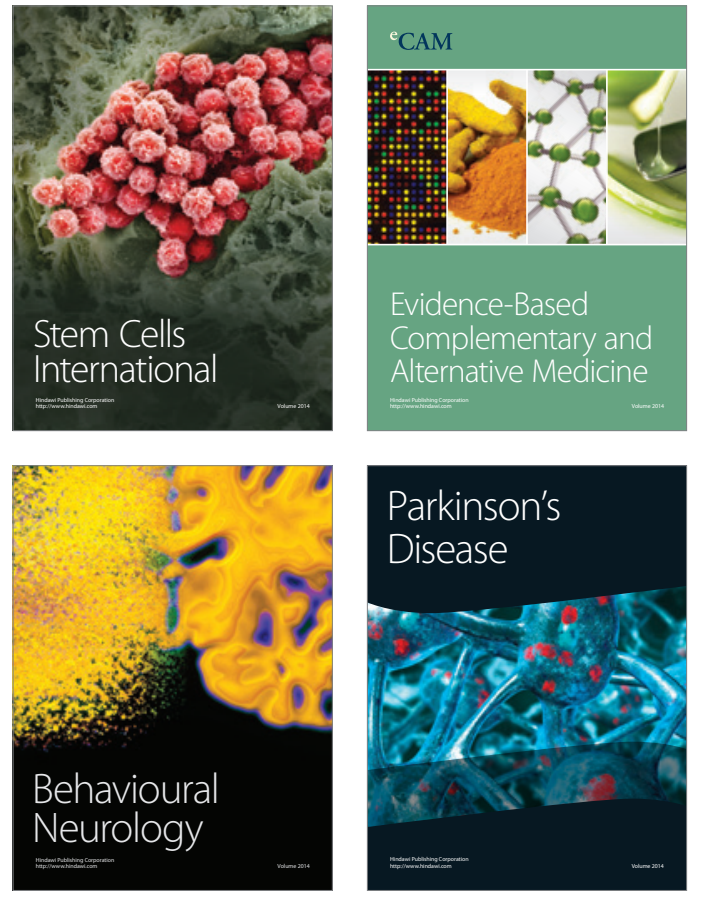
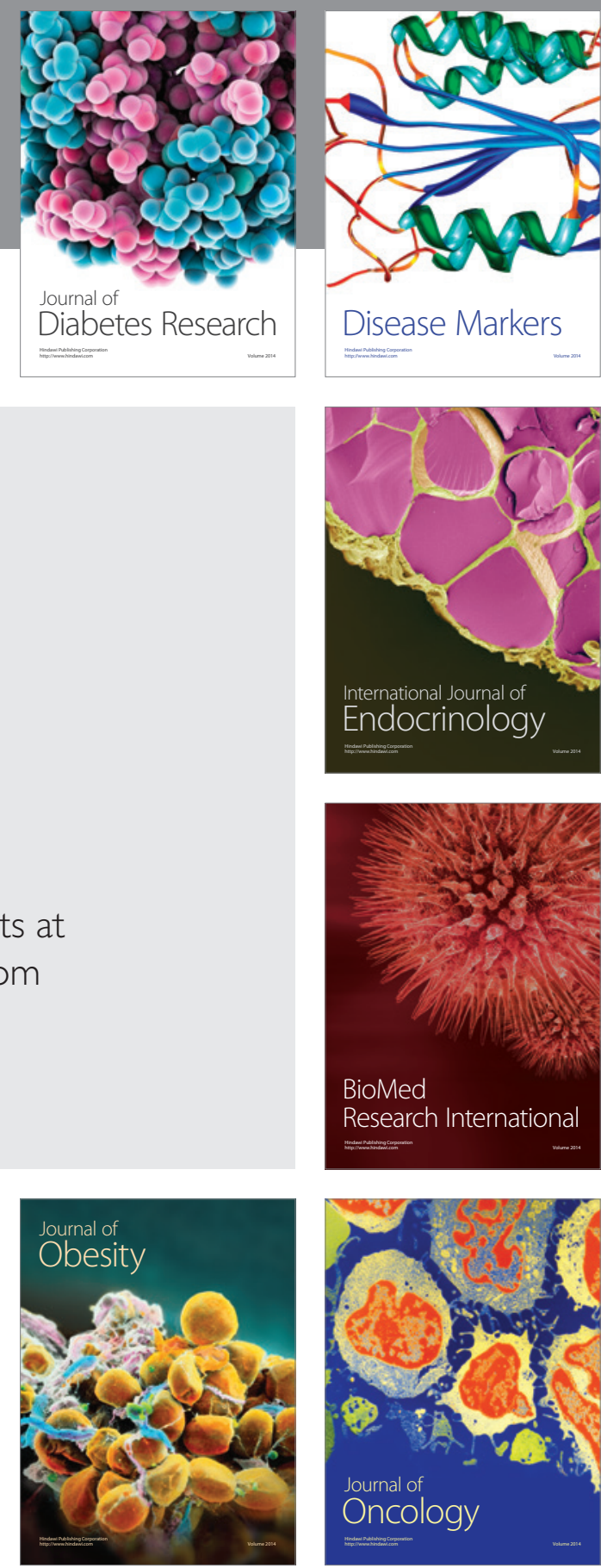

Disease Markers
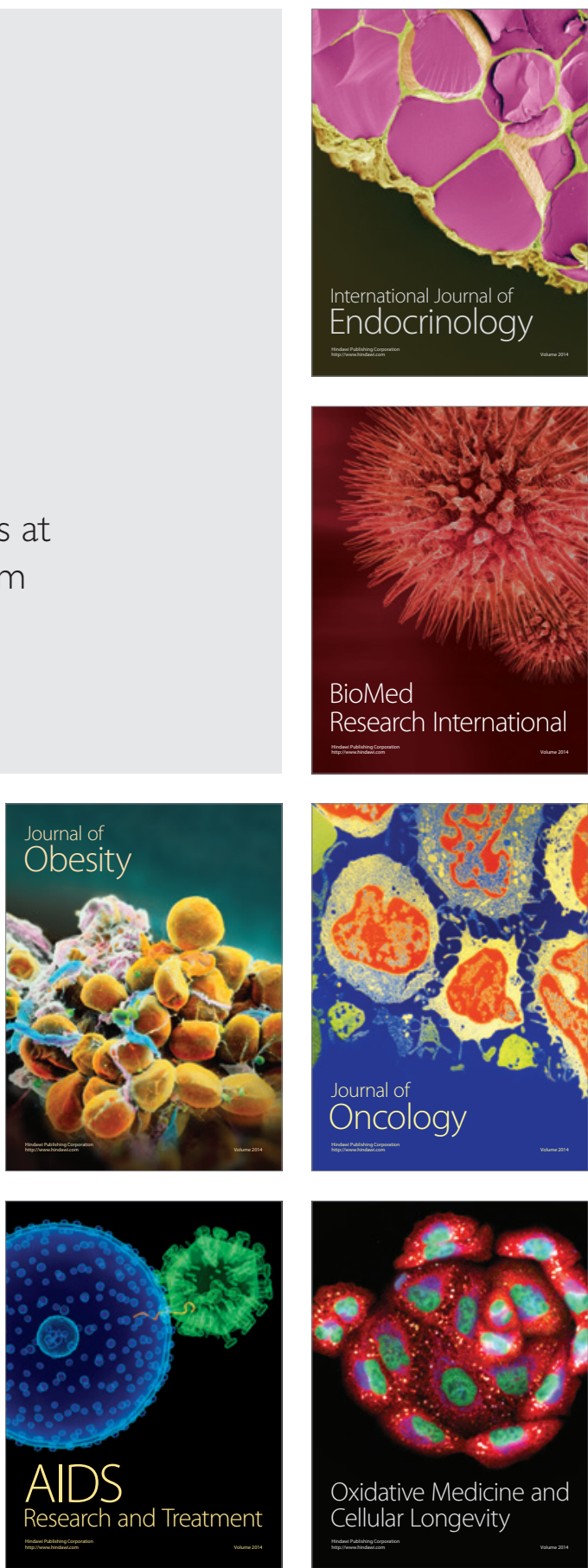